\title{
低水流出の低減特性に関する研究 \\ A STUDY ON THE RECESSION CHARACTERISTICS \\ OF GROUND WATER RUN-OFF
}

$\begin{array}{lcl}\text { 高 } & \text { 木 } & \text { 不 折** } \\ \text { By } & \text { Fusetsu } & \text { Takagi }\end{array}$

\section{1.まえがき}

近年，大都市を中心とする水不足は深刻な社会問題を ひき起こし，その結果，循環的な資源としての水の有効 利用についていろいると議論されている。また，近い将 来の急激な需要水量の增大に対処するためにも，現在利 用されずに海へ流れ去っている水の効果的な利用をはか らなければならない。そのためには，河川流出の実態を 的確に把握することがまず第一に肝要であろう。

わが国では，地域的に多少の違いはあるが，梅雨期， 台風期および降雪期に降水が集中するので，年間の流況 はかなり大きな変化を呈している。河川流出量はいろい ろの流出成分から成っていることは周知のとおりである が，表面流出と中間流出とを含む直接流出は，流量は大 きいが，比較的短期間の現象である。これに反して，長 期間にわたってほとんど絶えることのない地下水流出， すなわち間接流出は，流量とその変化は少ないが，長期 間の河川流出量の涵羕源となる現象である。したがっ て, この低水の流出機構の解明は，長期にわたる水循環

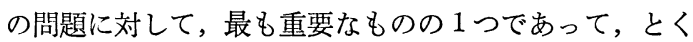
に，その低減特性は流出機構を間接的に示すものと考え られ，その究明が要望される。

従来，わが国においては，流出現象のうち主として短 期閒の異常な流出, すなわち洪水の流出問題の究明に力 が注がれてきたために，地下水流出は洪水解析の一部と して取り扱われ，低水問題として本格的に取り扱ったも のは少ないようである。

こうした意味において，本研究は流出機構という観点 から，低水流出の低減特性を考究しょうとしたものであ る。

\section{2. 従来の研究亡その検討}

低水流出は従来基底流または地下水流出などとして取 り扱われてきたが，物理的な意味から考えると，地下水 流出として考えるのが妥当であろう。一般に，無降雨期 間が続くと河川の流量は徐々に減少するが，その低減状 態がほぼ同じ性状を呈することは古くから認められてい る。したがって, この流量の低減特性に着目して低水の

\footnotetext{
* 37 年度関西支部学術講演会, 38 年度年次学術講演会にて 一部発表

** 正会員 工修 京都大学工学部土木工学教室
}

研究が進められてきたようであるが，以下従来の基本的 な考え方について述べるとともに，それらについて若干 の考察を加えよう。

\section{(1) 指数関数低減曲線}

Horner $^{1)}$, Flynt $^{1)}$, Barnes $^{2)}$ らは地下水流出の低滅状 態を時間に関する指数関数，すなわち

$$
Q=Q_{0} \cdot e^{-\alpha_{1} t}
$$

の形で表現した。ここに $Q_{0}$ は初期流量, $Q$ は時刻 $t$ における流量， $\alpha_{1}$ は定数である。

上式は多くの河川でかなりょく適合するとして使用さ れてきたが， $\alpha_{1}$ の值はその流域の状態を総合的に表現す るものとされ，その值の経験的評価に研究の重点がおか れてきた。流出の強度がその母体である貯留水量の残留 量に比例して減少寸ると考えると，これと連続式とから 式 (1) が導かれる。すなわち, 時刻 $t$ 亿おける流域内 貯留水量を $S$, 流出流量を $Q$, 比例定数を $\alpha_{1}$ とすると

$$
\frac{d S}{d t}=-\alpha_{1} S \text { および } \frac{d S}{d t}=-Q
$$

となるが，この式を初期条件 $(Q)_{t=0}=Q_{0}$ の下で解くと 式（1）が得られる。したがって， $\alpha_{1}$ の物理的意義もあ る程度うなづけるものがある。

しかし，実際の河川において，2支川が合流している 場合に，各支川からの流出量が式（1）で表わされると すると，その合流後の流量に対して同じ $1 つ の ~ \alpha_{1}$ の值 が対応するとはいいえない欠点がある。また実際の河川 の低減曲線は，ある程度の流量まで減少すると，それ以 後は徐々に低減が緩慢となり，このような 1 本の指数関 数では，長期間の低減は表わしにくいものが多い。

これらの欠点を補った考え方として，式（1）で表わ される特性をもったいくつかの成分が存在するものとし $\tau$

$$
Q=\sum_{j} Q(j) \cdot e^{-G(j) t}
$$

で河川流量低減を表現することがある3”。実際の流域で は地質の変化にともなって地下水帯が複雑に分布してお り，また多くの支川が合流していることを考えると，い くらか現象論的な裏付けをもつともいえるが，低減指数 $G(j)$ の物理的意義が不明のまま残されている。

一方，Horton は長期間渴水状態が続くときの一般式 として

$Q=Q_{0} e^{-\alpha_{2} t^{n}}$ 
を提案した。しかし，この式も式 (1) と同様に経験則 の域を出ないようである。ここに $\alpha_{2}$ および $n$ は流域固 有の定数としている。

\section{(2) 統計力学的取り扱い}

流量の低減特性を統計学的見地から取り扱った大久保 の研究がある4)。これは, 流域における地下水流出過程 の場が非常に複雑であって, 結果として現われるハイド ログラフは統計学的な伝播性分布となるとしたものであ る。すなわち，ピーク流量の日を第 0 日，それより $i$ 日 後の流量を $Q_{i}$ とした場合に

$$
i Q_{i} / Q_{i-1}=a+b(i-1)
$$

の関係が成立することを見出し, 大井川・天龍川で $a=$ $0.6 \sim 0.9, b \simeq 1$ の結果をえている。式 (4) は統計学 的には伝播性分布の 1 つである Polya-Eggenberger の 式と一致するところから, 大久保は流出機構を統計的立 場から説明しょうとした。この考え方は複雑な流域内の 現象を統計的に考察した点に大いに興味があるが，流体 力学的な流出の機構ということには難点がある。なお， 式 (4) は $a-b=0$ の場合には式 (1) と一致する。

\section{(3) 標準低減曲線}

河川の流量ハイドログラフのうち，無降雨期間の低減 曲線を別々に取り出して重ね合わせ，その時間軸をずら して小さい流量の部分が一致するようにするとき,これ らの曲線の包絡線を標準低減曲線という ${ }^{5}$ 。竹内はこの 標準低減曲線に漸近するような曲線に沿って河川流量が 低減するものとして, 標準低減曲線で示される流出成分 と, その上に乗る流出成分を分離した。さらに降雨によ って地下水流出流量は増加してどれほどの流量に達する か, すなわち標準低減曲線のどの点から低減が開始する かということを検討し，季節や降雨量との関連において 議論した。その中に含まれる物理的意義はあいまいのま ま残されているが，流域固有の標準低減曲線が存在する とし, その上昇特性などを具体的に表現した点が興味深 い。

\section{(4) 統計的取り扱い}

低水を扱うのに，低減曲線の形状を対象とするのでは なく, 時々刻々の流量を全く独立なものとして切りはな し,これらが確率的な事象として起こっていると考えた ものがある。わが国でよく用いられている流況曲線など もこうした考え方によるものの一つである。この考え方 は河川の低減特性といらより，季閒あるいは 1 年といっ た長期間の流況を知ることを主目的としている。しか し, この確率的表示によって, 河道近辺に貯留された水 の流出と流域からの一様な流出とを分離しょうとした試 みもなされている6)。

\section{(5) 従来の研究の検討}

実際の低水解析, 低减特性の解析にあたっては, その 目的・対象などの違いによっていろいろな方法がある。
しかし，それらの基本的な考え方は前項までに掲げた考 え方に尽くされるといってよいであろう。

さて，以上にあげた解析方法すべてに通じていえるこ とは，いずれの方法も経験則の域を出ていない。低減曲 線を数式で，あるいは図式的に表現してはいるもののそ の現象論的解釈は十分ではない。すなわち，それぞれの 式に含まれる諸要素の性格については多くの資料の比較 検討から推定されているにすぎず，その物理的意義はあ いまいなままに残されているようである。たとえば，指 数関数の場合, 指数が何を表現しているのか, なぜ流域 固有の低減曲線が生じるのかといった議論は少ない。た だ $\alpha_{1}, \alpha_{2}, n$ などが一定になるところから，これらが何 か流出を総合的に表現しているのであろうと見做してき たにすぎないようである。

また, 流出を統計力学的に解釈しようとした大久保の 試みも，その基礎は経験則式 (4) である。この関係式 を通じて伝播性分布と結びつけようとしたのであるが, 彼が行なったように 1 日単位に対して式（4）が成立す るときは, 時間単位を 2 日にするときは, もはや式 (4) は成立しなくなる。地下水流出のような問題の場合， 1 日単位を 2 日単位に変えただけで基礎的な関数形が変化 するとは考えられない。こうした点にまだ検討するべき 問題が残されているといえよう。

\section{3. 地下水の流出過程}

前節において従来の地下水流出に関する取り扱い方に ついて検討したが，今後その欠点を補ない，地下水流出 の問題をより明確に把握するためには，とくにその流出 の機構を明らかにする必要がある。そして，その内的・ 外的な機構を現象論的・物理的な立場から考察を進める ことがきわめて重要であるといわねね゙ならない。

さて，降雨のうち直接流出分および損失分を除いた残 部は, 地表から表層・中間層を経て, 変形を受けながら 地下水面に達する。地下水面に達した水の運動は一般に 飽和浸透で Darcy 則に従うものと考えられる。その運 動はきわめて緩慢であって，水は長期間にわたって貯留 の効果を受けたのち，地表・水みち・河道へと流れ出 し，表流水となって懸案地点に達する。この間，地表か ら地下水帯まで, 地下水帯内部, そして表流水となって からの $3 つ の$ 異なった流下過程を経るが, このうちで最 む大きな変形は地下水帯内部で生ずるものと考えてよい だろう。さらに，無降雨期間における流出量の低減特性 は, 雨水の供給という外的な条件が加わらないので，地 下水帯内部での変形, すなわち地下水帯の地域的分布や 形状・大きさ・保水能力などの効果を総合的に表現する ものと考えられる。

実際の地下水の存在状態や流出に影響をおよぼす諸要 素はきわめて複雑で, 個々の地下水帯について厳密に力 
学的解析をすることは不可能に近い。しかし, 地下水の 中に力学的に異なった挙動をする成分があれば，それら の成分は流出特性に違った効果を表わすはずである。

ところで, 地下水が地表に流出する状態を観察する と, 浸み出るものと湧き出るものとがある。浸み出ると いう現象は出口の近傍における圧力がほとんど大気圧に 等しいときに起こり, 湧き出るためには地下水流の圧力 が大気圧より高いことが必要である。一般に地下水帯に は自由水面をもつ不被圧地下水帯と境界が不透水性地層 で囲まれた被圧地下水帯とがある。そしてその中での地 下水の流動が前者は 拡散型, 後者は圧力 図-1 伝播型の機構である ことも周知のとおり である。したがっ て, 浸出する成分は 不被圧地下水帯から の流出であり，湧出 する成分は被圧地下 水帯からの流出であ ると考えることがで きるわけで，その模 様は図一1 に示すと おりである。

\section{4. 地下水の流出モデル}

実際の流域で，不被圧地下水帯と被圧地下水带が存在 するとしても，それらがどんな形状であるかを一般的に 示すことはかなりむずかしい。そこで，ここでは地下水 帯加ら流出の特性を示すと考えられる 図一2, 図一3 のようなモデルについて，流出量の低減特性を考察する ことにする。図一2 は不被圧地下水帯, 図一3 は被圧地 下水帯であって，いずれも単位幅当りに対するものとす る。図一3 上流端にあるタンクは水頭を表わすためのも

\section{図-2}

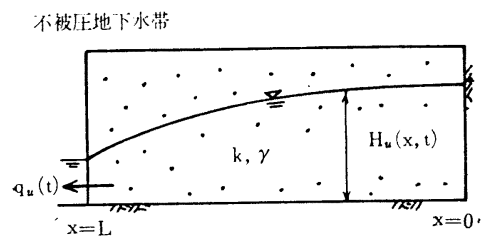

図-3

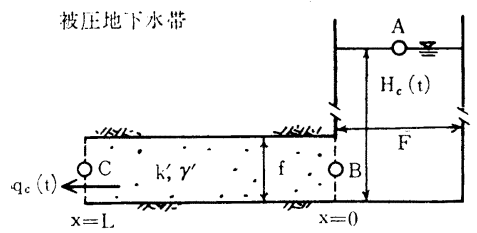

のである。諸記号は図に示したとおりであるが，

$q_{u}, q_{c}$ : 不被圧, 被圧地下水帯からの単位幅当り流出 流量

$r, r^{\prime}:$ 砂層の間げき率

$k, k^{\prime}:$ 砂層の透水係数

$L, l:$ 砂層の長さ

$F:$ 被圧地下水帯上流端タンクの単位幅当り断面 積

$f:$ 被圧地下水帯砂層の単位幅当り断面積 である。

\section{5. 基礎方程式とその解}

\section{（1）被圧地下水帯からの流出}

砂層内の平均流速を vとすると，図一 3 において連続 の式は

$$
f \cdot v=-F \frac{d H c}{d t}
$$

である。さらに，モデルのタンクと砂層とを一つの流管 と見做すと, Bernoulli 式が適用される。B 点での水頭 を $h_{B}$ とし, $\mathrm{A}$ 点での圧力を大気圧で 0 とすると, $\mathrm{AB}$ 間での Bernoulli 式は近似的に

$$
H_{c}+\frac{1}{2 g}\left(\frac{d H_{c}}{d t}\right)^{2}=\frac{1}{2 g} v^{2}+h_{B}
$$

同様に BC 間では,

$$
\frac{1}{2 g} v^{2}+h_{l}=\frac{1}{2 g} v^{2}+h_{B}
$$

となる。ここに $h_{l}$ は B C 間における水頭損失である が，BC 間の抵抗則は Darcy 則によって，

$$
h_{l}=l v / k^{\prime}
$$

と表わされる。

これらの 4 式が, 被圧地下水帯からの流出の低減に対 する基礎方程式で, この 4 式より,

$$
H_{c}=\frac{l}{k^{\prime}} v+\frac{1}{2 g}\left\{1-\frac{f^{2}}{F^{2}}\right\} v^{2}
$$

となるが，これを時間で微分して式（5）の関係を用い ると, $v$ に関する微分方程式

$$
-\frac{f}{F} v=\frac{l}{k^{\prime}} \frac{d v}{d t}+\frac{v}{g}\left\{1-\frac{f^{2}}{F^{2}}\right\} \frac{d v}{d t}
$$

が得られる。 $q_{c}=f v$ であることを考慮して，この式を 積分すると, 結局被圧地下水带加らの流量の時間的な低 減曲線として,

$$
-\frac{F l}{f k^{\prime}} \log _{e} q_{c}-\frac{F}{f^{2} g}\left\{1-\frac{f^{2}}{F^{2}}\right\} q_{c}=t+c
$$

が求められる。ここに，c 初期条件によって定まる定 数である。

\section{（2）不被圧地下水帯からの流出}

不被圧地下水帯の場合には自由水面があるので, 基礎 方程式を立てるに際して，水頭に対してある仮定をする 必要がある。ここではよく知られた Dupuit-Forchheimer の近似が成立して, 水面勾配は十分に小さく，任意 
の鉛直断面における流速は水面勾配に比例するものと考 える。

このように考えると, 砂層内の水流に対する式は図一 2 について, Darcy 則は

$$
v_{u}=-\frac{\partial}{\partial x}\left\{k \cdot H_{u}(x, t)\right\}
$$

連続式は

$$
\frac{\partial\left(r H_{u}\right)}{\partial t}=-\frac{\partial}{\partial x}\left\{H_{u} \cdot v_{u}\right\}
$$

となり,この 2 式より低減時の基礎式は

$$
\frac{\partial\left(r H_{u}\right)}{\partial t}=k H_{u} \frac{\partial^{2} H_{u}}{\partial x^{2}}+k\left(\frac{\partial H_{u}}{\partial x}\right)^{2}
$$

となるが， $r$ を一定とし，水面勾配 $\frac{\partial H_{u}}{\partial x}$ は小さいも のとして $\left(\frac{\partial H_{u}}{\partial x}\right)^{2}$ を無視すると

$$
\begin{gathered}
\frac{\partial H_{u}}{\partial t}=\beta H_{u} \frac{\partial^{2} H_{u}}{\partial x^{2}} \\
\beta=k / \gamma \cdots \cdots \cdots \cdots \cdots \cdots \cdots \cdots
\end{gathered}
$$

となる。

この式を解くために, 境界および初期条件が必要であ る。しかし,害際にはこれらの条件は未知であって,これ らを与えることはできない。河道の水位は地下水帯に対 しては境界条件として, 地下水帯の水の挙動は河水の供 給源として, 両者は相互に関連しあい, ともに一方が定 まらないと, 数式として表現できないからである。しか し, 洪水のような場合と異なり, 地下水流出の場合には 河道の水位が地下水流出を制御するというょりは, むし ろ地下水流出が河道水位を支配していると考えられる。 また, ここでの研究対象が主として地下水流出の時間的 変動であることを考えると, 河道水位の変動を時間的に 規定しても無意味であろう。

このように考えて式 (13) の未知関数 $H_{u}(x, t)$ に対 する条件として，つぎのものを用いた。

初期条件

$$
\begin{aligned}
& H_{u}(0,0)=H_{0}, \\
& H_{u}(L, 0)=h_{0},
\end{aligned}
$$

境界条件

$$
\left(\frac{\partial H_{u}}{\partial x}\right)_{x=0}=0 .
$$

さて, 式 $(13)$ の $H_{u}(x, t)$ を位置の関数と時間の関数 の積で表わされるものとして変数分離した後, 式 (15), (16)，(17）の条件に対する固有值問題として式（13）を 解くと, その解は

$$
\begin{aligned}
H_{u}(x, t)= & \frac{1}{\frac{2 \beta}{L^{2}}\left(H_{0}-h_{0}\right) t+1} \\
& \times\left\{-\frac{H_{0}-h_{0}}{L^{2}} x^{2}+H_{0}\right\}
\end{aligned}
$$

となる。

そして, $x=L$ での流量, すなわち流出流量 $q_{u}(t)$ は

$$
\begin{aligned}
q_{u}(t) & =k H_{u}(L, t) \cdot\left|\frac{\partial H_{u}(x, t)}{\partial x}\right|_{x=L} \\
& =\frac{2 k}{L}\left\{\frac{1}{\frac{2 \beta}{L^{2}}\left(H_{0}-h_{0}\right) t+1}\right\}^{2} h_{0}\left(H_{0}-h_{0}\right)
\end{aligned}
$$

で与えられる。この $x=L$ での初期流量を $q_{u}(L, 0) \equiv$ $q_{u 0}$ とすると

$$
q_{u}(t)=\frac{q_{u 0}}{\left\{\frac{2 \beta}{L^{2}}\left(H_{0}-h_{0}\right) t+1\right\}^{2}}
$$

となる。すなわ方

$$
a=\frac{2 \beta}{L^{2}}\left(H_{0}-h_{0}\right)
$$

とおくと

$$
q_{u}(t)=\frac{q_{u 0}}{\{a t+1\}^{2}}
$$

で表わされることになる。

\section{6. 低減曲線の方程式}

以上述べたように，不被圧成分の低減曲線の方程式は 式 (21) で与えられ，時間に関する陽関数となっている が, 被圧成分に対する式 (9) は陰関数であるから, 取 り扱いやすい陽関数に書き換える。そのために, 式 (9) の各項が流出にどの程度貢献しているかを検討しよう。 いま単位として $\mathrm{km}$, day を用いると, 透水係数 $k^{\prime}$ は ほぼ $10^{-6} \sim 10^{-7}, g$ は $10^{-2}$ のオーダーであり, 一方 $F l / f$ と $F^{2} / f$ のつはオーダー的にほぼ同じであると 思われるので, 式 (9) の左辺第 2 項は第 1 項に比し十 分小さく, その流出に対する効果は無視することができ る。したがって, 近似的に式 (9) の低隇曲線の式は指 数関数となると考えてよい。事実式 (9) を片対数紙上 にプロットすると，その形状は大体図一4のようにな り, 時間の経過とともに速やかに

$$
-\frac{F l}{f k^{\prime}} \log _{e} q_{c}=t+c
$$

の直線に漸近していること がわかる。図-4 汳想的 に計算したものであるが, 実際の漸近のようすはもっ と速やかであると考えられ る。さて, この直線と $q_{c}$ 軸との交点を $q_{c 0}$ とすれ ば， $q_{c 0}$ は被圧地下水帯か らの初期の流出流量に近似 的に等しく, 低減曲線は近

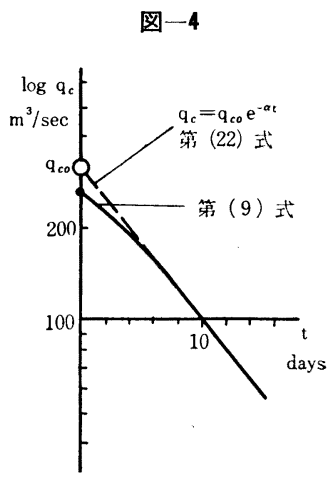
似的に式 (9) の第 2 項を 無視した次式で表わされることになる。

$$
q_{c}(t)=q_{c 0} \cdot e^{-\alpha t}
$$

ただし， 
$\alpha=f k^{\prime} / F \cdot l$

この被圧, 不被圧両成分の低減を表わす式 (23) およ び式 (21) は, モデルの単位幅当りの流量であるから, 実際の流域に適用するには, その流域の大きさの効果を 考える必要がある。これを考虑したときの河川流量を $Q$, 被圧・不被圧地下水帯からの流出分を $Q_{c}, Q_{u}$, そ れらの初期值をそれぞれ $Q_{0}, Q_{c 0}, Q_{u 0}$ と表わし, $L, l$ を一定とした場合の平均的な流出口の幅を表わす $B_{c}, B_{u}$ を導入すると，

$$
\left.\begin{array}{l}
Q_{u}=B_{u} \cdot q_{u} \\
Q_{c}=B_{c} \cdot q_{c}
\end{array}\right\}
$$

と表わすことができる。ゆえに各成分は

$$
\begin{aligned}
& Q_{u}=Q_{u 0} /(a t+1)^{2} \\
& Q_{c}=Q_{c 0} \cdot e^{-\alpha t} \ldots . .
\end{aligned}
$$

で表わされる。さらに, 実際の河川の流量はこの 2 つの 成分からなっているから

$$
Q=Q_{c}+Q_{u}=Q_{c 0} \cdot e^{-\alpha t}+Q_{u 0} /(a t+1)^{2}
$$

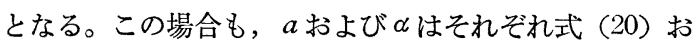
よび式 (23) で与えられるが，これらは流域での低減の 様子を総合的に表わす因子と考えておこう。

$$
\text { ところで }
$$

$$
\lim _{t \rightarrow \infty} \frac{Q_{c}}{Q_{u}}=\lim _{t \rightarrow \infty} \frac{Q_{c 0}}{Q_{u 0}} e^{-\alpha t} \cdot(a t+1)^{2}=0
$$

であるから, 被圧成分は不被圧成分に比べてはるかに速 やかに低減する。すなわち, 無降水日数がある程度以上 になると, 被圧地下水帯からの流出は事実上終了してし まって, 河水はすべて不被圧成分のみからなると考えて 差し支えない。式 (26) の低減状態を定める因子は初期 流量 $Q_{c 0}, Q_{u 0}$ と低減の程度を示す $\alpha, a$ の值であって, これらが地下水流出の低減におよぼす諸特性を総合的に 表現するものと解釈してよい。

以上, 上でえられた結果を基礎として，実際の河川に 適用した例を考えながら, 低減部の諸性質について論じ ていくことにしよう。

\section{7. 解析資料亡諸特性量の決定}

解析の対象は, 兵庫県加古川の国包上流流域, 奈良県 紀ノ川水系吉野川の寺尾上流流域, 京都府由良川の荒倉 および角上流流域である。これらの流域の概要を 図一5 に解析した流量低減部を 表一1 に示したが，資料とし ては上記各流量観測所における日流量（定時観測值）と 上流流域の日雨量である。

実際の流出解析を行なうには, 被圧・不被圧両成分の 初期流量 $Q_{c 0}, Q_{u 0}$ および，それぞれの低減の割合を示

\begin{tabular}{|c|c|c|c|c|}
\hline \multicolumn{5}{|c|}{ 表一1 } \\
\hline 川 & $\begin{array}{l}\text { 測水所 } \\
\text { 流域面積 }\end{array}$ & 記 号 & 最大流量日 & $\begin{array}{c}\text { 最大流量 } \\
\mathrm{m}^{3} / \mathrm{sec}\end{array}$ \\
\hline 加 古 川 & $\begin{array}{l}\text { 国 包 } \\
1674 \mathrm{~km}^{2}\end{array}$ & $\begin{array}{l}\mathrm{K}-1 \\
\mathrm{~K}-2 \\
\mathrm{~K}-3 \\
\mathrm{~K}-4 \\
\mathrm{~K}-5 \\
\mathrm{~K}-6 \\
\mathrm{~K}-7 \\
\mathrm{~K}-8 \\
\mathrm{~K}-9\end{array}$ & $\begin{array}{l}\text { 1950. 3. } 7 \\
1954.7 .20 \\
1954.7 .31 \\
1954.9 .29 \\
1956.7 .24 \\
1956.9 .27 \\
1956.10 .31 \\
1957.7 .28 \\
1958.7 .4\end{array}$ & $\begin{array}{r}828.1 \\
196.7 \\
229.0 \\
187.3 \\
184.3 \\
1722.0 \\
370.5 \\
304.0 \\
218.0\end{array}$ \\
\hline 吉 野 川 & $\begin{array}{l}\text { 寺 尾 } \\
253 \mathrm{~km}^{2}\end{array}$ & $\begin{array}{l}Y-1 \\
Y-2 \\
Y-3 \\
Y-4 \\
Y-5 \\
Y-6\end{array}$ & $\begin{array}{l}1949.7 .6 \\
1951.7 .13 \\
1952.11 .5 \\
1955.7 .24 \\
1955.8 .27 \\
1958.7 .23\end{array}$ & $\begin{array}{r}68.1 \\
357.3 \\
225.3 \\
128.5 \\
1331.4 \\
145.6\end{array}$ \\
\hline 由 良川 & $\begin{array}{l}\text { 荒 倉 } \\
159 \mathrm{~km}^{2}\end{array}$ & $\begin{array}{l}\text { A-1 } \\
\text { A-2 } \\
\text { A-3 } \\
\text { A-4 } \\
\text { A-5 } \\
\text { A-6 } \\
\text { A-7 } \\
\text { A-8 } \\
\text { A-9 }\end{array}$ & $\begin{array}{l}1950.8 .3 \\
1950.10 .6 \\
1953.6 .8 \\
1953.7 .5 \\
1953.9 .26 \\
1954.7 .6 \\
1955.6 .19 \\
1955.7 .7 \\
1956.7 .24\end{array}$ & $\begin{array}{r}88.6 \\
52.8 \\
90.7 \\
172.1 \\
331.8 \\
35.8 \\
15.5 \\
36.6 \\
92.3\end{array}$ \\
\hline & $\begin{array}{c}\text { 角 } \\
585 \mathrm{~km}^{2}\end{array}$ & $\begin{array}{l}K^{\prime}-1 \\
K^{\prime}-2 \\
K^{\prime}-3 \\
K^{\prime}-4 \\
K^{\prime}-5 \\
K^{\prime}-6 \\
K^{\prime}-7\end{array}$ & $\begin{array}{l}1949.7 .30 \\
1949.10 .6 \\
1952.7 .11 \\
1954.7 .30 \\
1955.7 .7 \\
1955.7 .24 \\
1956.7 .24\end{array}$ & $\begin{array}{r}229.0 \\
69.2 \\
386.2 \\
66.6 \\
78.2 \\
13.2 \\
251.8\end{array}$ \\
\hline
\end{tabular}
す $\alpha, a$ を求める必要がある。

さて, 低水解析をする場合, まず問題になるのは, 何 時から河川が低水状態, 寸なわち地下水流出分のみの状 態になるかということである。この時刻としては, 表面

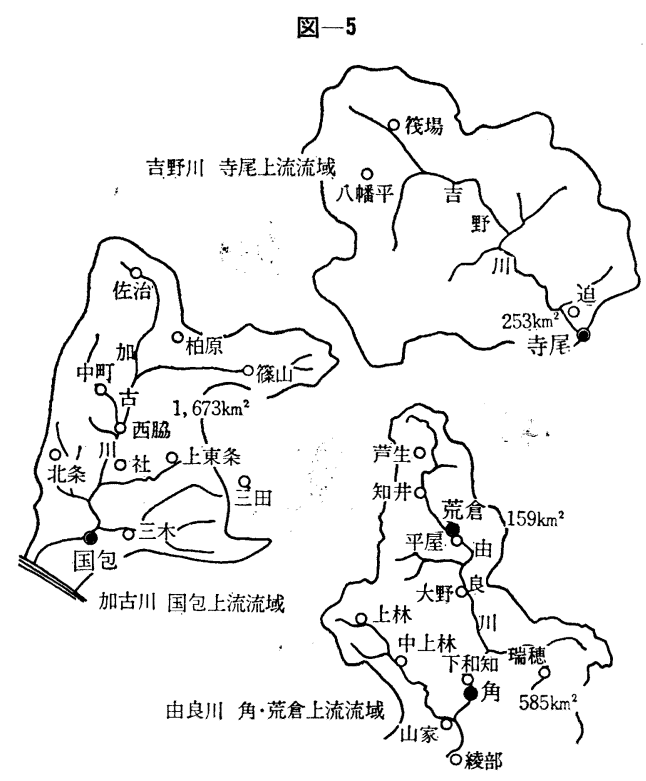

流出と中間流出すなわち直接流出が終了したときを採用 すればよいわけである。しかし，直接流出の終了時刻を 厳密に定めることは非常に困難である。とくに日単位の 資料を用いると不明瞭な点が少なくない。そこで，わが 国の多くの洪水解析の結果と流域面積とを勘案しで7, 
中間流出が終了し地下水流出分のみとなる時刻を一応つ ぎのようにして解析を行なった。

加古川・国包：最大流量日より 3 日後

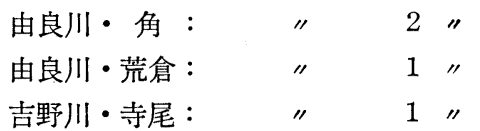

前述したように，低減がある日数以上続いた場合に は, 河川流量はすべて不被圧成分のみから成るので, こ の性質を利用すれば，地下水流出分より不被圧成分を分 離することができる。すなわち, 河川流量が不被圧成分 のみより成ると考えられる期間の流量資料にもとっとも 適合するように式 (25) a をあてはめ, 時間原点まで外挿 することによって $Q_{u 0}, a$ の值が定められる。こうして 求めた $Q_{u 0}, a$ の值を用いると式 (25)a によって不被圧 成分の低減曲線が求められる。

一方，被圧成分はこの不被圧成分を実測流量から引き 算して求められ，この被圧成分を半対数紙上にプロット すると, 一般に一直線上に並ぶ。これらの点に最適の直 線を挿入するとその勾配が $\alpha$ となる。直線の適合に際し ては対数紙であることを考慮し, 時間原点における被圧 成分の值を尊重して $Q_{c 0}$ とした。

実際に $Q_{u 0}, a$ を定める場合にあてはめる式 (25)a は 曲線であるから，その適合の程度をとらえるのがむずか しく, 最小自乗法を用いるのも計算が繁雑となる。しか し, 式 (25)a は

$$
\sqrt{\frac{1}{Q_{u}}}=\sqrt{\frac{1}{Q_{u 0}}} \cdot(a t+1)
$$

と変形されるから， $\sqrt{1 / Q_{u}}, t$ を縦横軸とすれば, 不被 圧成分の低減曲線は一直線で表わされる。この直線と時 間原線との交点が $\sqrt{1 / Q_{u 0}}$ を与え, 勾配が $a \sqrt{1 / Q_{u 0}}$ と 尔るからこれらから $Q_{u 0}, a$ を決定することができ

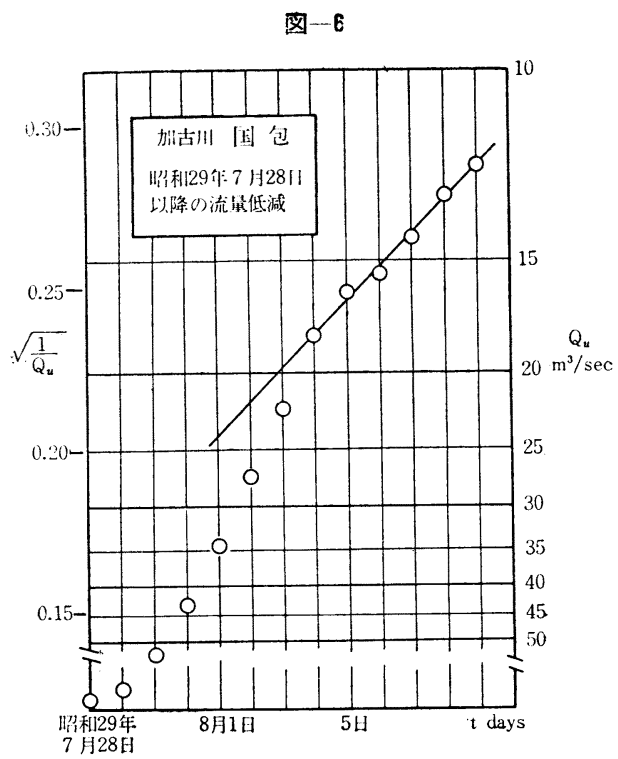

る。図一6 はこのようにして直線を挿入した例である が, プロットが時間の経過とともに直線に漸近し，ある 程度以上日数がたつと河川流量が不被圧成分のみから成 っている様子がわからう。この直線の勾配は一つの流量 観測所についても必らずしも一定になるとは限らない。

以上のようにして解析した諸量の結果をとりまとめた のが 表一2 である。

表一2

\begin{tabular}{c|c|c|r|r}
\hline 資 & $\begin{array}{c}Q_{u o} \\
\mathrm{~m}^{3} / \mathrm{sec}\end{array}$ & $\begin{array}{c}a \\
1 / \text { day }\end{array}$ & $\begin{array}{r}Q_{c o} \\
\mathrm{~m}^{3} / \mathrm{sec}\end{array}$ & $\begin{array}{c}\alpha \\
1 / \mathrm{day}\end{array}$ \\
\hline $\mathrm{K}-1$ & 82.9 & 0.089 & 53.3 & \\
$\mathrm{~K}-2$ & 28.2 & 0.028 & 6.9 & - \\
$\mathrm{K}-3$ & 19.5 & 0.024 & 23.5 & 0.387 \\
$\mathrm{~K}-4$ & 38.4 & 0.024 & 16.6 & 0.363 \\
$\mathrm{~K}-5$ & 15.9 & 0.061 & 16.4 & 0.421 \\
$\mathrm{~K}-6$ & 77.2 & 0.079 & 26.8 & 0.431 \\
$\mathrm{~K}-7$ & 47.2 & 0.061 & 21.3 & \\
$\mathrm{~K}-8$ & 41.6 & 0.106 & 27.4 & 0.504 \\
$\mathrm{~K}-9$ & 22.3 & 0.024 & 28.7 & 0.554 \\
\hline $\mathrm{Y}-1$ & 18.6 & 0.019 & 23.9 & 0.569 \\
$\mathrm{Y}-2$ & 46.0 & 0.084 & 109.7 & 0.618 \\
$\mathrm{Y}-3$ & 15.7 & 0.037 & 37.0 & 0.628 \\
$\mathrm{Y}-4$ & 13.8 & 0.023 & 64.0 & 0.626 \\
$\mathrm{Y}-5$ & 28.6 & 0.055 & 109.4 & 0.719 \\
$\mathrm{Y}-6$ & 17.8 & 0.043 & 61.8 & 0.642 \\
\hline $\mathrm{A}-1$ & 4.7 & 0.027 & 24.0 & 0.774 \\
$\mathrm{~A}-2$ & 8.0 & 0.037 & 17.1 & 0.462 \\
$\mathrm{~A}-3$ & 12.2 & 0.055 & 40.0 & 0.770 \\
$\mathrm{~A}-4$ & 22.2 & 0.079 & 92.2 & 0.618 \\
$\mathrm{~A}-5$ & 16.0 & 0.054 & 18.4 & 0.685 \\
$\mathrm{~A}-6$ & 18.2 & 0.066 & 1.3 & - \\
$\mathrm{A}-7$ & 4.9 & 0.027 & 14.5 & 0.613 \\
$\mathrm{~A}-8$ & 7.7 & 0.048 & 14.4 & 0.620 \\
$\mathrm{~A}-9$ & 7.7 & 0.032 & 30.6 & 0.648 \\
\hline $\mathrm{K}-1$ & 23.2 & 0.017 & 26.0 & 0.300 \\
$\mathrm{~K}^{\prime}-2$ & 27.0 & 0.027 & 6.1 & 0.366 \\
$\mathrm{~K}^{\prime}-3$ & 66.0 & 0.136 & 1.4 & - \\
$\mathrm{K}-4$ & 16.4 & 0.069 & 10.9 & 0.790 \\
$\mathrm{~K}^{\prime}-5$ & 14.6 & 0.042 & 22.0 & 0.525 \\
$\mathrm{~K}^{\prime}-6$ & 5.3 & 0.057 & 1.5 & 0.742 \\
$\mathrm{~K}^{\prime}-7$ & 29.3 & 0.067 & 16.1 & 0.847 \\
\hline & & & & \\
& & & & \\
\hline
\end{tabular}

\section{8. 被圧地下水流出分の低減特性}

被圧地下水帯からの流出の低減曲線は,

$$
Q_{c}=Q_{c 0} \cdot e^{-\alpha t}
$$

で与えられる。

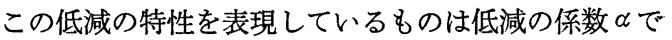
あるが，式 (23) $\alpha=f k^{\prime} \mid F l$ によると，この $\alpha$ を形成し ている要素は, 被圧地下水帯の形状を定める因子 $F, f$, $l$ とその透水度を総合的に表現した透水係数 $k^{\prime}$ である。 一般にこれらは特定の流域にあっては季節的には変化せ ず，ほぼ一定であると考えられる。すなわち，この低減 係数 $\alpha$ は流域で不変の地形・地質的要素のみに支配され ており，いわゆる被圧地下水流出に対して流域特性を表 わしているものと解釈される。したがって，前述したモ デルでもってある地点より上流の流域からの地下水流出 
図一7

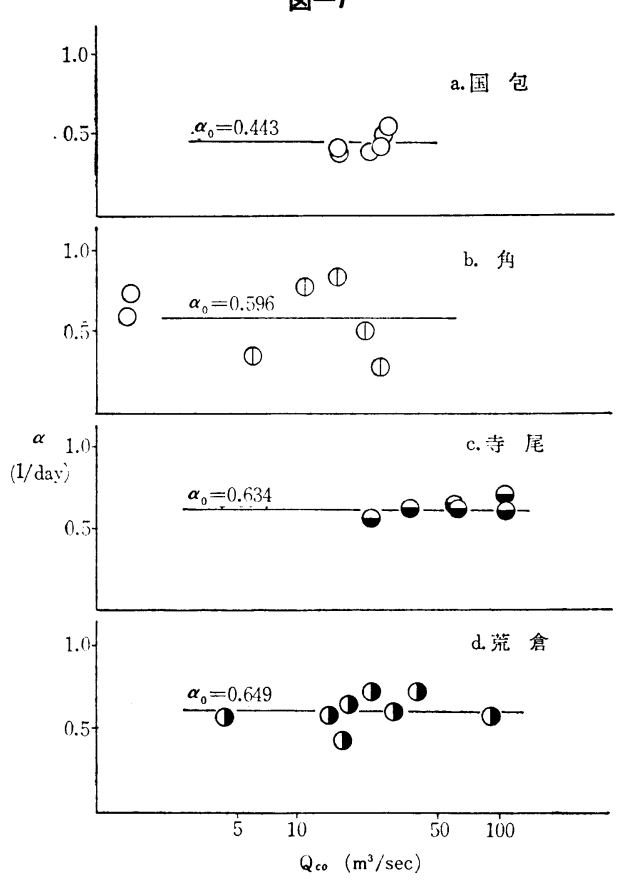

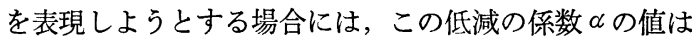
初期条件のいかんにかかわらず流域固有の定数でなけれ ばならない。加古川国包，吉野川寺尾，由良川角および 荒倉, 各地点での解析による $\alpha$ の值を $Q_{c 0}$ に対してプロ ットすると，図一7 のようになる。図中に直線で示した $\alpha_{0}$ の值は, 各流域の $\alpha$ の平均值である。

図一7 から各流域で初期流量のいかんにかかわらず, 被圧地下水帯からの地下水流出の低減特性值 $\alpha$ はほぼ一 定であることがわかる。

しかし，よりくわしく観察すると，流域面積が小さい

図-8(a)

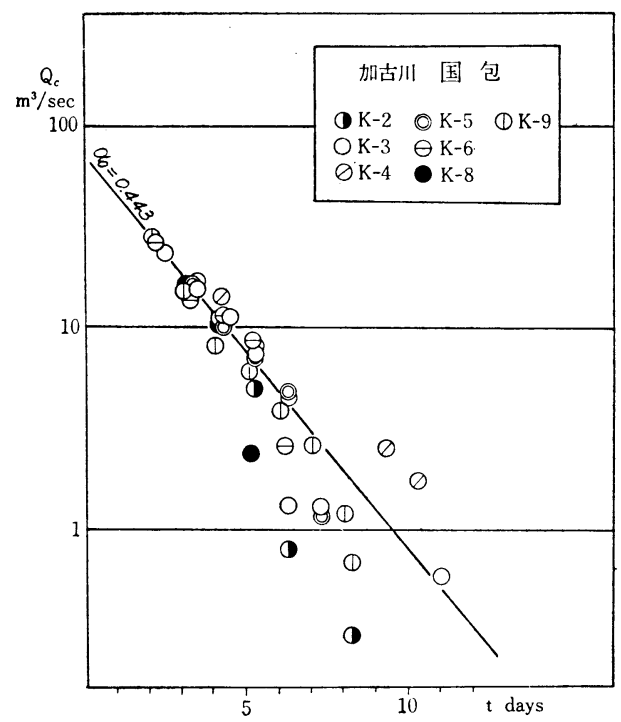

場合には一定となっているが，由良川角，加古川国包な どの場合には若干ばらついている。このばらつきの原因 は明らかではないが，流域面積が大きくなると流出に影 響をおよぼす要素が流域に一様ではないので，降雨の場 所的分布の不斉や諸用水など，人為的な影響によるもの と思われる。

いずれにしても，全体的に判断すると $\alpha$ は各流域で一 定であると考えてよい。 おり式 (25)b は指数型低減曲線であって，その曲線は片 対数紙上で 1 本の直線となるはずである。図一8 は解析 した各低減部の各日の被圧地下水成分の值を示したもの である。ただし，解析資料は時間軸をずらしてプロット してある。図から大略式 (25)b の低減曲線に沿って流量

図-8(b)

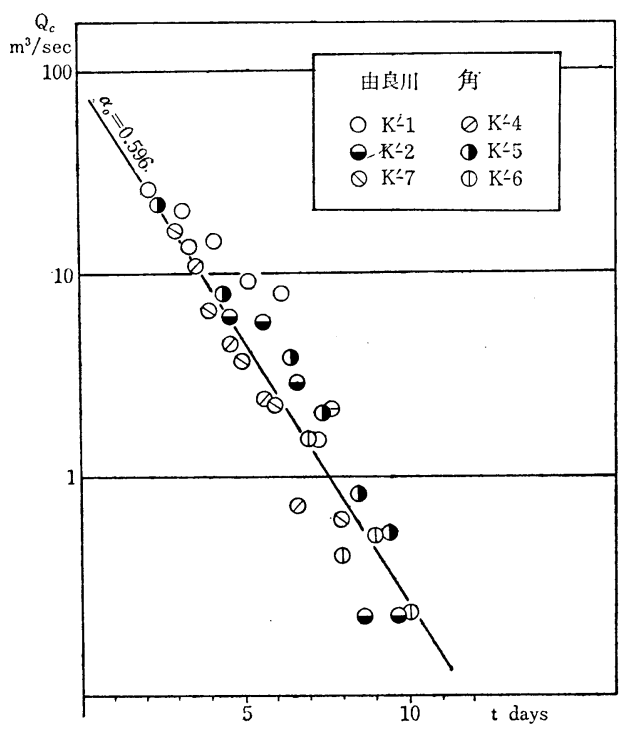

図-8(c)

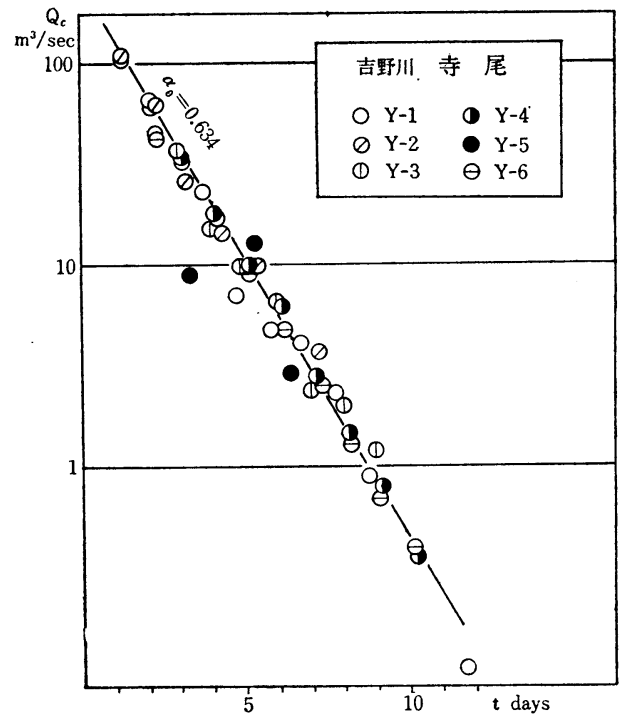


図-8(d)

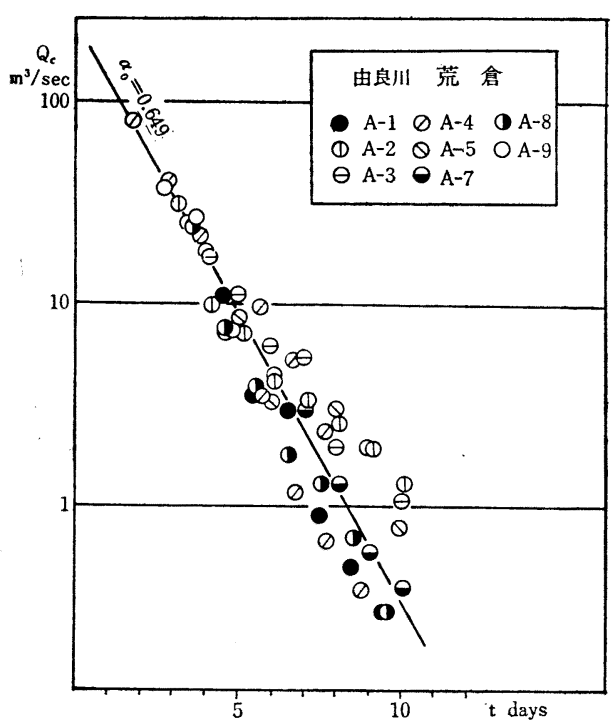

が低減していると考えてよいであろう。

ここで取り上げたモデルはあまりに簡単なものである から，自然界における複雑な地下水流出の現象を完全に 解明したとはいえないまでも, 水の流動の力学的性格の 一つである圧力伝播型に注目するとき, 指数関数的低減 をする成分の存在が推測され，かつその低減係数の性格 をより一層明らかにすることができたものといえよう。

\section{9. 不被圧地下水流出分の低減特性}

不被圧地下水帯からの流出の低減曲線は,

$$
Q_{u}=Q_{u 0} /(a t+1)^{2},
$$

ただし，

$$
a=2 \beta\left(H_{0}-h_{0}\right) / L^{2},
$$

で与えられる。この場合には, 被圧成分の場合とは異な り, 片対数紙上において勾配が徐々に減少する低減曲線 となって，長期間の低減状態をより精度よく表現するこ とができる。

不被圧成分の低減の状態は, 初期流量 $Q_{u 0}$ と低減の 割合を示す $a$ によって表現される。 $a$ の值を形成してい る要素は式 (14) および (20) より $L, k, r$ と低減初期 の状態を示す $H_{0}, h_{0}$ であるが, $L, k, r$ は流域の地形・ 地質の様子を総合的に表現したものであって各流域では 一定の值と考えられる。したがって，一つの流域にあっ ては $a$ の值は初期条件によって定まる定数でなければな らない。ところで, 初期流量 $Q_{u 0}$ は初期の地下水帯内 の上流水深 $H_{0}$ と下流水深 $h_{0}$ の関数であるとともに, $a$ もまたこれらの関数である。したがって, この $H_{0}$, $h_{0}$ を媒介として, 初期流量 $Q_{u 0}$ と低減特性值 $a$ の間に は何らかの関数関係があることが想像される。

いま, 不被圧地下水流出の低減曲線が, 初期状態を異 々するあらゆる場合に 1 本の曲線で表わされるものとす
図-9

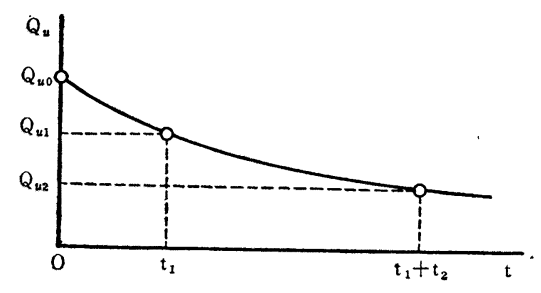

る。この場合には, 図一 $\mathbf{9}$ に示すように, $t=0, t_{1}, t_{1}+$ $t_{2}$ における流量をそれぞれ $Q_{u_{0}}, Q_{u_{1}}, Q_{u_{2}}$ とすると式 (25) a より

$$
\begin{aligned}
& Q_{u_{1}}=Q_{u_{0}} /\left\{a t_{1}+1\right\}^{2}, \\
& Q_{u_{2}}=Q_{u_{0}} /\left\{a\left(t_{1}+t_{2}\right)+1\right\}^{2}
\end{aligned}
$$

であり， $Q_{u 1}$ を初期流量として $Q_{u 2}$ を表わすと

$$
Q_{u_{2}}=Q_{u_{1}} /\left\{a^{\prime} t_{2}+1\right\}^{2}
$$

が成立する。このとき $a^{\prime}$ は $t=t_{1}$ を時間原点としたと きの $a$ の值を示す。これらの式が $t_{1}, t_{2}$ のいかんにかか わらず成立するという条件を用いると結局

$$
\frac{a}{a^{\prime}}=\sqrt{\frac{Q_{u_{0}}}{Q_{u_{1}}}}
$$

が成立する。すなわち, 初期流量のいかんにかかわらず 1 本の曲線に沿って流量が低減するためには,

$$
a=K \cdot \sqrt{Q_{u 0}} \text {. }
$$

の関係が成立していなければならない。ここで $K$ は比 例定数である。

解析した不被圧成分の低減曲線を，時閒軸をずらして できるだけ同一の曲線にのるようにした結果が 図一10 であり, 初期流量 $Q_{u 0}$ と $a$ との関係を図示したものが 図一11である。図一10(d) より, 流域面積の小さい山 岳流域の由良川荒倉では, 不被圧地下水成分の低減が, 1 本の曲線に沿って減衰していることがわかる。したが って, 式 (29) が成立し, 図一11において $a$ と $Q_{u_{0}}$ の 間にほぼ放物線的関係が成立する。他の地点でもこのよ うな傾向がうかがわれるが，図一11 からもわかるよう

図-10(a)

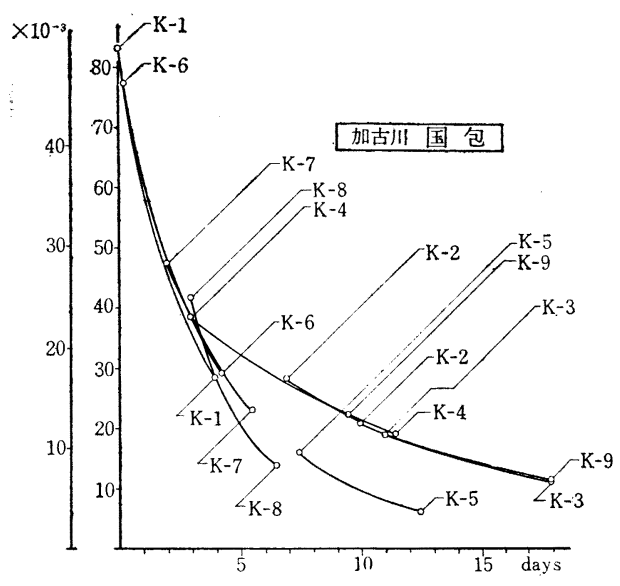


図-10 (b)

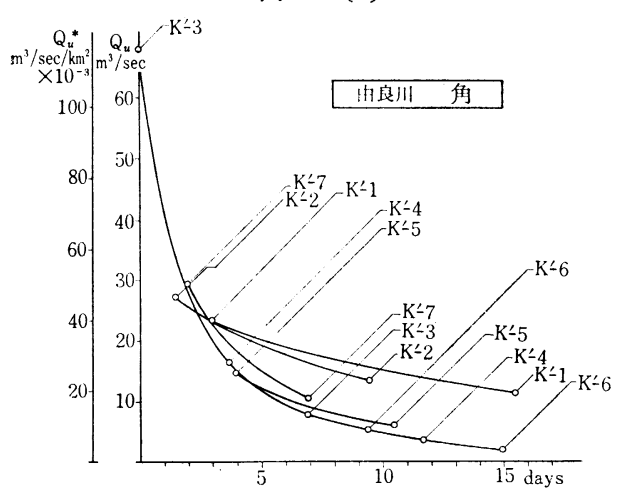

図-10(c)

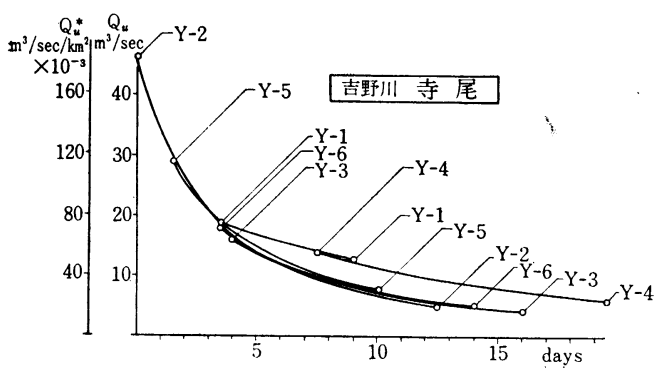

図-10 (d)

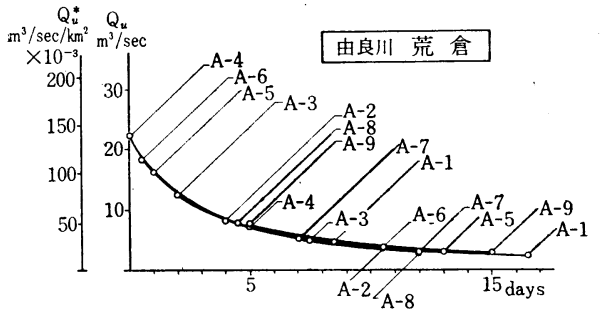

図-11

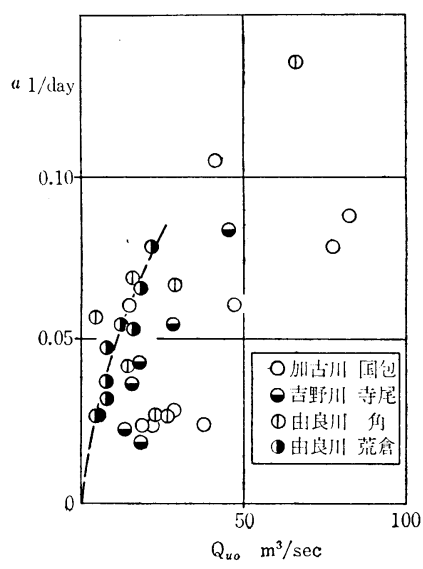

に，場合場合によって低減の様子が変化しているので明 確にはわからない。とくに流域面積が大きいほどそのば らつきも大きくなっているようである。

\section{0. 低減特性に影響を与える要素}

一つの流域における被圧・不被圧地下水成分の流出低 減状態には，それぞれ異なった傾向がみられた。とく に，流域面積の小さい山岳流域である荒倉地点では，両 成分ともその流出は初期状態のいかんにかかわらず同じ 1 本の曲線に沿って低減している。しかし，図一7，8， 10，11 をみると，いずれの成分の場合にも，低減状態 のばらつきは流域面積が大きいほど大きくなっている。

地下水流出の低減特性が主として流域の物理的特性に 支配されることはすでに述べたとおりであるが，一方， 降雨の地域分布が変化すると, 初期条件としての流域地 下水の存在状態が変わるので, これによっても低減状態 は影響を受けるはずである。こうした要素の流域での分 布状態は, 当然流域面積が大きいほど複雑となるから, 上に述べたように流域面積が大きくなると一定の低減状 態を示さなくなるものと考えられる。しかし，低減状態 に影響をおよぼすいろいろな要素の分布状態は非常に複 雑なので，これらを考慮して低減曲線を一般的に論じる ことはきわめて困難であるといわねばならない。ここで は解析した個々の流域の結果について，こうした観点か ら若干の考察をするに止める。

\section{（1）被圧地下水成分について}

図一7 をみると, 解析した $\alpha_{0}$ の值は流域面積の増加 とともに少しずつ減少している。 $\alpha$ 構成する要素は仮 想的な $F, f$ と透水層の長さを示す $l$, および透水係数 $k^{\prime}$ である。このうち $F, f$ は地質構造によって定まるも ので, 水頭の効果をモデル的に表現したものであるか ら，これを基としていくつかの流域の $\alpha$ の值を比較検討 することは困難である。また透水係数についてもここで 扱っている各流域でさほど異なっているとは考えられ ず，とくに角・荒倉地点などではほぼ等しいと考えてよ いであろう。流域の大小によって ると，その差異は $l$ の違いによるものが最も大きな要素 であろう。

ここで解析した流域について, 流域面積と $\alpha_{0}$ の值を プロットすると 図一12 のようになり，流域面積の増加 とともに $\alpha_{0}$ の值が 図-12 減少する傾向がうか がえる。いま, 流域 面積と $l$ とが比例関 係にあると, 式(23) $\alpha=f k^{\prime} / F l$ の関係か ら, 流域面積と $\alpha_{0}$ とは反比例の関係に なり, 図一12 と傾 向的に一致すること がわかり， $\alpha_{0}$ の值の

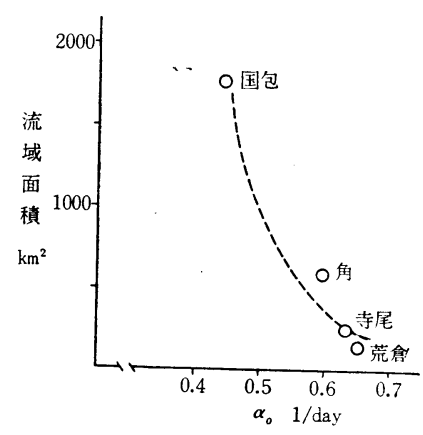


性格をある程度知ることができる。

\section{（2）不被圧地下水成分について}

降雨の場所的分布が不被圧流出分の低減状態に影響を およぼすと考えられるが，その様子は角・寺尾の場合に 顕著に現われている。角地点上流流域の日雨量を調べる 之, 資料 $\mathrm{K}^{\prime}-3,4,5,6,7$ の場合では下流地点下和知か ら上流の芦生まで，降雨は全流域にほとんど一様に分布 している。これに対して，上流部に非常に集中した雨の ある $\mathrm{K}^{\prime}-1$ の場合には，図一10(b) からみられるよう に低減状態が緩慢になっている $\left(\mathrm{K}^{\prime}-2\right.$ の場合の降雨量は 久測)。このように, 流域に一様な降雨のあるときに比 し，上流部に雨が集中するときに，同一流量に対する低 減の割合が緩慢となる傾向は，吉野川寺尾でも観察され る。すなわち，図一10 (c) 資料 $\mathrm{Y}-4,5$ についてみる と, 両者の場合の流域平均の日雨量には大きな差はない が, 後者では流域にほぼ一様に分布しているのに対し， 前者では下流迫地点で $100 \mathrm{~mm} /$ day 以下，上流筏場で $300 \mathrm{~mm} /$ day 以上と上流部に雨が集中している。そして, 低減曲線の傾向は後者は緩慢, 前者の方が急となってい る。角および寺尾でのこうした傾向は，両流域とも上流 部からの流出の低減が沛るく，下流部からの流出が急で あることを示唆するものと考えられる。

低減曲線のばらつきのほとんどない荒倉, 比較的ばら つきの少ない寺尾上流流域はともに山地流域で, 流域面 積は前者は $159 \mathrm{~km}^{2}$, 後者は $253 \mathrm{~km}^{2}$ であって, 流出の 上ではその規模・特性が似ていると考えられる。このこ とは, 両地域の不被圧成分の 単位面積当りの流量 $Q_{u}$ * の低減状態（図一10 (c)，(d) に付記) p，単位面積当 りの初期流量 $Q_{u_{0}}{ }^{*}$ と $a$ の関係 (図一13) がよく一致し ていることからもうかがうことができる。さらに，解析 した範囲では, 図一13 に示すように流域面積が小さい ほど，同じ $Q_{u 0}{ }^{*}$ に対する $a$ の值が小さく，したがっ て，低隇が緩慢之なっている。しかし，こうした傾向が 山地部と下流平地部での, 不被圧地下水流出の挙動が違 うためだとしても，なぜ上記のような傾向となるのか， その原因は明らかではない。

図-13

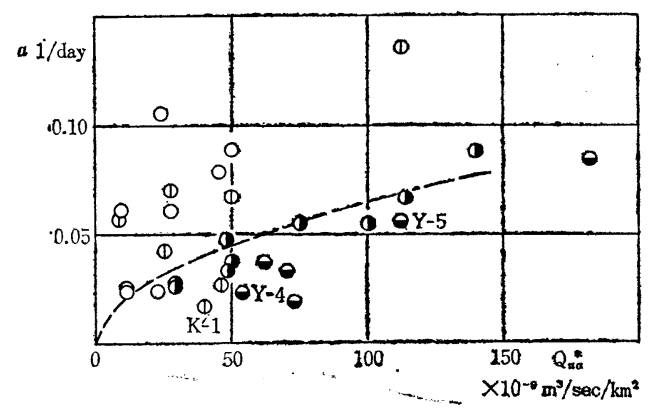

\section{1. むすび}

以上，低水流出を地下水流出と考え，その流量低减特 性を流出機構という観点から検討した。その際，抬散 型・圧力伝播型といら水の流動の力学的性格に着目し, 不被圧・被圧地下水帯に対するモデルを想定して，この モデルにおける水の流動機構を基礎として検討したが， 本研究によってえられた結果は以下のとおりである。

1. 被圧地下水成分は指数型低減をし，その低減の係 数 $\alpha$ は流域固有の值である。他方, 不被圧地下水成分の 低減は分数関数で表わされ, その低減は被圧分に比しは るかに緩慢である。したがって，長期間の河水はこの不 被圧流出分によって涵養されているものと考えることが できる。

2.このような不被圧成分の導入によって, 従来 1本 の指数関数では説明しにくかった長期間の低滅状態を把 握することができる。

3. 流域面積の小さい山地流域では, 被圧・不被圧両 成分とも, 初期流量いかんにかかわらず，それぞれ1本 の曲線に沿って流量が低減し，その変動はきわめて少な 、。不被圧分の低減状態を示す $a$ の值は, 流域固有の要 素と初期条件によって支配されるが，このような小さい 山地流域では $Q_{u}$ と $a$ の間には放物線的関係が成立す る。

4. 流域面積によって低隇の割合を示す $\alpha, a$ の值が変 化している。被圧分の場合は $\alpha$ と流域面積の間にほぼ反 比例的関係が認められたが，不被圧分の場合はあまり明 確ではないが, 解析した範囲内では, 単位面積当りの初 期流量が同じとき， $a$ の值は流域面積の増加とともに大 きくなっている。

5. 流域面積が大きくなると， 2 成分の低減状態のば らつきが大きくなる。これは流域が大きくなると，流出 に影響する要素が地域的に変化するからであるう。その 要素の一つとして, 降雨の場所的分布の影響がかなり大 きいことが観察された。

本研究で用いたモデルはあまりにも簡単なもので, 数 学上の難点などもあり，モデル自体および各種条件の選 定の仕方などが制約されたので, 低減部のもつ物理的意 義を十分解明しえたとはいえないが, このような地下水 流出を取り扱う上での問題点を反省し, 今後の参考に資 したいと思う。

ここで用いたモデルは, あくまでも㦟案地点上流流域 全体での流出特性を総合的に表現したものであって, 上・中・下流各地域からの流出過程むこのような機構に 支配されるものとすると, 当然各地域で $\alpha, a$ などの值 は異なるものと考えられ，奬案地点での低減の様子を一 つの指数や, 分数関数では表現できないであろう。この ことはまた，性質を異とする二つ以上の河川の分合流前 
後での低減を説明するにも若干の矛盾を含んでいる。

流出を考える場合, 流域は実際にはいろいろな性質の 部分から成るものと思われ, 個々の単位流域からの流出 の性質の合成として, 镙案地点の河水を把えるべきであ ろう。本研究の結果, 流域面積が小さいとき, 上記モデ ルがかなりよく低減特性を表現したことは, 荒倉程度の 流域ならば,一つの単位流域として取り扱いらることを 示唆している。前項に述べた事柄と関連し, 低水問題を 扱うとき, 対象とすべき単位流域をどのように選定する かは, 今後の重要な問題であろう。

こうした問題に加え, 単位流域内における流出現象自 体が統計的要素を含んでいることを思うと, 低水の実態 を把握するには, 水の力学的挙動とともに統計的要素を 導入し, 、わゆる統計力学的観点から研究を進めるべき だと考えられる。

さらに, この研究を行なうに当り, 地下水の挙動と低 水に関する観測資料が少なく, 研究の妨げになり, 早急 に観測の充実化をはからなければならないことを痛感し た。今後これらの事柄を指針として, 低水流出の問題や 水資源における表流水の問題をも勉強していきたいと考
えている。

終りに臨み, 本研究を行なうにあたり, ご指導下さっ た京都大学教授 石原藤次郎先生, 同防災研究所教授 石 原安雄先生に心から感謝の意を表します。

$$
\text { 参考 文 献 }
$$

1) Horner and Flynt : A.S.C.E. (1938) 野満隆治・瀬野錦藏著 : 新河川学, 第 3 章 第 4 節, 地人 書館, 昭 34 年による。

2) Barnes, B.S. : The Structure of discharge-recession curves, Trans. Amer. Geo. Union (1939) p. 731.

3）菅原正已・臀良知 : 雨量から流量を算出する方法につい $\tau$, 電気学会誌, 第 78 巻, 833 号, 昭 33.2 , など

4) 大久保辰雄: 河川の流出機構について, 電力気象連絡会 彙報, 第 2 輯, 第 2 巻, 第 1 号, 昭 29.1 .

5）竹内拨雄 : 地表水, 水資源講座 2 , 土木学会誌, 46-11, 昭 36.11 .

6）たとえば George R. Kunkle : The Baseflow-Duration Curve, a Technique for the Study of Groundwater Discharge from a Drainage Basin, Jour. of Geophysical Research, Vol. 67, Apr. 1962, No. 4 pp. 1543

7）たとえば石原藤次郎 - 石原安雄・高棹㙇馬・頼千元：由 良川の出水特性に関する研究, 京都大学防災研究所年報,

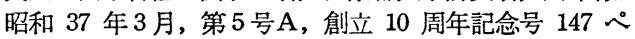
ージ.

(1965.9.9 - 受付) 